慶應義塾大学学術情報リポジトリ

Keio Associated Repository of Academic resouces

\begin{tabular}{|c|l|}
\hline Title & Determination of inorganic phosphate by the use of immobilized enzymes in a FIA system \\
\hline Sub Title & \\
\hline Author & $\begin{array}{l}\text { 森, 久和(Mori, Hisakazu) } \\
\text { 小暮, 真美絵(Kogure, Mamie) } \\
\text { 川俣, 寿美代(Kawamata, Sumiyo) } \\
\text { 永本, 昭子(Nagamoto, Akiko) } \\
\text { 山本, 晴彦(Yamamoto, Haruhiko) }\end{array}$ \\
\hline Publisher & 共立薬科大学 \\
\hline Publication year & 1993 \\
\hline Jtitle & $\begin{array}{l}\text { 共立薬科大学研究年報 (The annual report of the Kyoritsu College of } \\
\text { Pharmacy). No.38 (1993.),p.70- 70 }\end{array}$ \\
\hline JaLC DOI & \\
\hline Abstract & \\
\hline Notes & 抄録 \\
\hline Genre & Technical Report \\
\hline URL & https://koara.lib.keio.ac.jp/xoonips/modules/xoonips/detail.php?koara_id=AN00062898-0000003 \\
\hline 8-0070
\end{tabular}

慶應義塾大学学術情報リポジトリ(KOARA)に掲載されているコンテンツの著作権は、それぞれの著作者、学会または出版社/発行者に帰属し、その権利は著作権法によって 保護されています。引用にあたっては、著作権法を遵守してご利用ください。

The copyrights of content available on the KeiO Associated Repository of Academic resources (KOARA) belong to the respective authors, academic societies, or publishers/issuers, and these rights are protected by the Japanese Copyright Act. When quoting the content, please follow the Japanese copyright act. 
No. 38 (1993)

\title{
Determination of Inorganic Phosphate by the Use of Immobilized Enzymes in a FlA System*
}

\author{
Hisakazu Mori, Mamie Kogure, Sumiyo Kawamata, Akiko Nagamoto \\ and Haruhiko YAMAMOTO** \\ 森 久和, 小暮真美絵, 川俣寿美代, 永本昭子, 山本晴彦**
}

Inorganic phosphate was fluorometrically determined in the FIA system with a column containing co-immobilized enzymes for successive reactions to generate NADPH from inorganic phosphate. The enzymes used were sucrose phosphorylase, phosphoglucomutase and glucose-6-phosphate dehydrogenase, and they were co-immobilized on aminopropyl glass. Assay conditions such as flow rate of a carrier solution and column temperature were investigated for optimization. Several buffers of different $\mathrm{pHs}$ were examined as a carrier solution to find Tris buffer ( $\mathrm{pH} \mathrm{8.0)} \mathrm{most} \mathrm{favorable.} \mathrm{Under} \mathrm{the} \mathrm{conditions,} \mathrm{the}$ calibration curve for the determination of inorganic phosphate ( $50 \mu \mathrm{l}$ injection) showed a linear relationship in the concentration range of $0.2-100 \mu \mathrm{M}$. The detection limit was 0.1 $\mu \mathrm{M}$, that is, 5 pmol. The relative standard deviation of the peak area for $10 \mu \mathrm{M}$ sample was $4.1 \%(\mathrm{n}=5)$. The analysis of a sample completed in $10 \mathrm{~min}$. This method was applied to the determination of phosphorus content in the calf thymus DNA. The content obtained was coincident with that obtained by the molybdenum blue method.

* 本報告は Anal. Lett. に発表。 (in press).

** 神奈川大学理学部 